\title{
GALLERY WALK: STRATEGI UNTUK MENGOPTIMALKAN KETERLIBATAN MAHASISWA DALAM PEMBELAJARAN MATEMATIKA
}

\author{
Nur Qomaria \\ Universitas Trunojoyo Madura \\ nur.qomaria@trunojoyo.ac.id
}

\begin{abstract}
ABSTRAK
Gallery walk adalah strategi pembelajaran aktif yang mendorong mahasiswa untuk berdiskusi, bertanya, menyampaikan gagasan secara lisan dan tulisan melalui aktivitas ekshibisi/pameran poster. Penelitian ini bertujuan untuk mengetahui keterlibatan (engagement) mahasiswa dalam pembelajaran matematika dengan strategi Gallery Walk. Keterlibatan yang diukur meliputi keterlibatan kognitif, afektif, dan perilaku. Data dikumpulkan melalui angket dan observasi. Subjek penelitian ini adalah 35 mahasiswa program studi pendidikan IPA Universitas Trunojoyo Madura yang menempuh mata kuliah matematika dasar. Analisis data dilakukan dengan menentukan persentase banyaknya mahasiswa yang merespon pada kriteria tertentu perindikator keterlibatan, baik untuk angket maupun lembar observasi. Hasil penelitian menunjukkan bahwa keterlibatan kognitif mahasiswa yang meliputi regulasi diri, motivasi, dan strategi mendalam tergolong baik. Keterlibatan afektif yang mencakup ketertarikan, orientasi terhadap prestasi, dan orientasi terhadap teman sejawat tergolong baik. Keterlibatan perilaku yang terdiri dari frekuensi bertanya, terlibat dalam diskusi, menjelaskan kepada teman sejawat juga tergolong baik. Dengan demikian, strategi gallery walk dapat diterapkan dalam pembelajaran matematika untuk mengoptimalkan keterlibatan mahasiswa.
\end{abstract}

Kata kunci : gallery walk, strategi pembelajaran, keterlibatan

\begin{abstract}
Gallery walk is an active learning strategy that encourages students to discuss, ask questions, convey ideas verbally and in writing through exhibit activities / poster exhibitions. This study aims to determine the involvement of students in learning mathematics with the Gallery Walk strategy. Measured involvement includes cognitive, affective, and behavioral involvement. Data collected through questionnaire and observation. The subjects of this study were 35 students of the Natural Sciences study program at Trunojoyo University, Madura, who took basic mathematics courses. Data analysis was performed by determining the percentage of the number of students who responded to certain criteria of involvement indicators, both for the questionnaire and the observation sheet. The results showed that the cognitive involvement of students which included self-regulation, motivation, and in-depth strategies was classified as good. Affective involvement which includes interest, orientation towards achievement, and orientation towards peers is classified as good. Behavioral involvement consisting of frequency of asking, engaging in discussion, explaining to peers is also quite good. Thus, the gallery walk strategy can be applied in mathematics learning to optimize student involvement.
\end{abstract}

Keywords : gallery walk, learning strategies, involvement 


\section{PENDAHULUAN}

Matematika yang merupakan dasar dari ilmu pengetahuan merupakan mata kuliah wajib bagi mahasiswa calon guru Ilmu Pengetahuan Alam (IPA). Menurut Zhu (2018) matematika di tingkat perguruan tinggi dikenal sebagai mata kuliah yang cukup sulit dipelajari disebabkan oleh tiga hal yaitu: 1) karakteristik matematika, 2) kebiasaan belajar mahasiswa, 3) strategi mengajar dosen. Matematika di tingkat perguruan tinggi cenderung menyajikan masalah-masalah yang lebih kompleks dan menuntut keterampilan berpikir tingkat tinggi. Menurut Liu (2012) dalam pembelajaran matematika masih banyak mahasiswa yang tidak terlibat aktif di kelas. Oleh karena itu, dibutuhkan desain pembelajaran yang dapat menjaga mahasiswa tetap termotivasi untuk belajar dan membuat mahasiswa lebih terlibat dalam pembelajaran. Menurut Chen, Lambert, dan Guidry (2010) keterlibatan peserta didik dalam pembelajaran memiliki pengaruh signifikan pada hasil belajar. Keterlibatan peserta didik dalam pendidikan tinggi telah menjadi area yang disorot secara konsisten karena memiliki pengaruh signifikan terhadap hasil belajar, termasuk keberhasilan penyelesaian studi (Redmond, dkk, 2018).

Keteribatan adalah waktu dan energi yang dicurahkan peserta didik untuk kegiatan yang berhubungan dengan pendidikan, baik di dalam maupun di luar kelas, serta partisipasi peserta didik dalam kebijakan dan praktik yang diterapkan oleh sekolah (Kuh, 2003). Keterlibatan (engagement) terdiri dari tiga dimensi yaitu keterlibatan kognitif, afektif, dan perilaku (Fredrick's, Blumenfeld and Paris, 2004). Keterlibatan kognitif mencakup timbulnya gagasan, pengakuan akan nilai, regulasi diri, strategi metakognitif, dan kemauan belajar ekstra; keterlibatan afektif mencakup perasaan peserta didik terhadap tempat belajar, rasa aman, mengekspresikan kegembiraan dan ketertarikan belajar, memiliki hubungan positif dengan teman dan pengajar, serta menganggap sekolah sebagai sesuatu yang berharga; keterlibatan perilaku mencakup aspek perhatian, kehadiran, konsentrasi, partisipasi, kepatuhan pada aturan, reaksi terhadap tempat belajar, pengajar, dan teman sebaya (Chapman, 2003; Pagan, 2018). Untuk menilai keterlibatan peserta didik secara efektif, aspek yang ditentukan harus jelas. Seperti yang diuraikan oleh Bowen (2005), keterlibatan peserta didik dapat didefinisikan dalam empat aspek yang saling terkait: 1) keterlibatan dengan proses pembelajaran (misalnya pembelajaran aktif); 2) keterlibatan dengan objek studi (misalnya pembelajaran berbasis pengalaman belajar); 3) keterlibatan dengan konteks studi (misalnya pembelajaran multidisiplin); dan 4) keterlibatan dengan kondisi manusia (misalnya pembelajaran sosial).

Strategi pembelajaran matematika berkembang seiring dengan perkembangan pengetahuan dan teknologi. Berbagai strategi telah diterapkan dalam kelas matematika, mulai tingkat dasar sampai tingkat tinggi. Strategi pembelajaran yang relevan dengan kebutuhan saat ini mengacu pada pendekatan peserta didik sebagai pusat pembelajaran atau Student Centered Learning (SCL) yang memungkinkan peserta didik memiliki lebih banyak kesempatan untuk terlibat dalam pembelajaran. Beckers, dkk (2015) menyatakan bahwa pendekatan SCL menekankan bahwa pembelajaran diterapkan melalui hubungan sosial yang kuat dan kolaborasi dengan sesama peserta didik dan fasilitator. Dengan pendekatan ini peserta didik secara signifikan terlibat di dalam kelas dan menjadi semakin bertanggung jawab atas pembelajaran mereka sendiri (Wilson, 2004).

Strategi gallery walk merupakan salah satu strategi yang mengacu pada pendekatan SCL. Gallery walk merupakan strategi pembelajaran yang mendorong 
peserta didik mengungkapkan pendapat dan idenya melalui media poster (Bowman, 2005). Penerapan gallery walk mendorong diskusi kelas, meningkatkan higher order thinking skills, pembelajaran kooperatif, dan team building (Dinata dan Anggraini, 2017; Septiana dan Sunarti, 2019). Langkah strategi gallery walk meliputi 1) penentuan topik, 2) pembagian kelompok kecil, 3) diskusi dalam kelompok, 4) ekshibisi (pameran) poster, 5) refleksi (Allen \& Larmer, 2013). Pada tahap awal, ditentukan beberapa topik yang akan dibahas. Selanjutnya dibagi kelompok kecil yang masing-masing mendiskusikan topik tertentu. Hasil diskusi disajikan dalam bentuk poster yang menarik dan merepresentasikan ide dengan jelas. Langkah selanjutnya, mahasiswa akan berkeliling kelas untuk melihat pekerjaan kelompok lain, menerima penjelasan dari perwakilan kelompok penyaji, memberikan pertanyaan dan komentar, serta berbagi gagasan. Untuk menyamakan persepsi dan menghindari kesalahan konsep, dilakukan refleksi melalui diskusi kelas yang difasilitasi oleh dosen.

Sebagai strategi pembelajaran dengan pendekatan SCL, penerapan gallery walk diharapkan mampu mengoptimalkan keterlibatan mahasiswa dalam pembelajaran matematika. Penelitian ini bertujuan untuk mengetahui bagaimana keterlibatan mahasiswa calon guru IPA dalam kelas matematika pada topik eksponen dan logaritma menggunakan strategi gallery walk. Keterlibatan yang diukur meliputi tiga dimensi keterlibatan yaitu kognitif, afektif, dan perilaku. Dengan mengetahui keterlibatan mahasiswa, maka dosen mendapatkan informasi yang dapat digunakan sebagai bahan evaluasi desain pembelajaran yang diterapkan dalam kelas matematika.

\section{METODE}

Penelitian ini merupakan penelitian deskriptif kualitatif. Subjek penelitian adalah 35 mahasiswa program studi Pendidikan Ilmu Pengetahuan Alam (IPA) Universitas Trunojoyo Madura semester 1 yang sedang menempuh mata kuliah matematika dasar. Penelitian dilakukan pada semester gasal tahun akademik 2019/2020. Penelitian ini berfokus pada keterlibatan mahasiswa dalam pembelajaran matematika dengan strategi gallery walk pada materi eksponen dan logaritma. Keterlibatan yang diukur terdiri dari tiga dimensi yaitu keterlibatan kognitif, afektif, dan perilaku. Indikator keterlibatan yang digunakan dalam penelitian ini merupakan adaptasi dari Butler dalam Mandernach (2015) dan Qomaria (2017). Indikator tersebut disajikan pada tabel 1 berikut ini.

Tabel 1. Indikator keterlibatan

\begin{tabular}{cll}
\hline Dimensi keterlibatan & & \multicolumn{1}{c}{ Indikator } \\
\hline Kognitif & 1. & Regulasi diri \\
& 2. & Motivasi \\
& 3. & Strategi mendalam \\
\hline Afektif & 1. & Ketertarikan \\
& 2. & Orientasi terhadap prestasi \\
& 3. & Orientasi terhadap teman sejawat \\
\hline Perilaku & 1. & Frekuensi bertanya \\
& 2. & Frekuensi terlibat dalam diskusi kelompok \\
& 3. & Frekuensi menjelaskan pada teman sejawat \\
\hline
\end{tabular}


Data tentang keterlibatan kognitif dan afektif diambil melalui angket, sedangkan data tentang keterlibatan perilaku diukur melalui observasi. Angket menggunakan skala Likert dengan skala 1-4 dengan kriteria 4: sangat setuju; 3: setuju; 2: kurang setuju, 1; tidak setuju. Lembar observasi juga menggunakan skala 1-4 dengan kriteria 4: sering; 3: kadang-kadang; 2: jarang, 1: tidak pernah. Analisis data dilakukan dengan menentukan persentase banyaknya mahasiswa yang merespon pada kriteria tertentu perindikator keterlibatan, baik untuk angket maupun lembar observasi.

\section{HASIL DAN PEMBAHASAN}

Hasil pengisian angket tentang keterlibatan mahasiswa secara kognitif dalam pembelajaran matematika dengan strategi gallery walk disajikan dalam tabel 2 berikut ini.

Tabel 2. Persentase keterlibatan kognitif dalam pembelajaran matematika dengan strategi gallery walk

\begin{tabular}{|c|c|c|c|c|c|}
\hline \multirow[t]{2}{*}{ Indikator } & \multirow[t]{2}{*}{ Item pernyataan } & \multicolumn{4}{|c|}{ Banyaknya responden (\%) } \\
\hline & & $\begin{array}{c}4 \\
(\mathrm{SS})\end{array}$ & $\begin{array}{c}3 \\
(\mathrm{~S})\end{array}$ & $\begin{array}{c}2 \\
(\mathrm{KS})\end{array}$ & $\begin{array}{c}1 \\
(\mathrm{TS})\end{array}$ \\
\hline \multirow[t]{3}{*}{ Regulasi Diri } & $\begin{array}{l}\text { 1. Saya berusaha menghubungkan topik } \\
\text { pembelajaran hari ini dengan konsep- } \\
\text { konsep yang pernah saya pelajari }(+) \text {. }\end{array}$ & 54,29 & 45,71 & 0,00 & 0,00 \\
\hline & $\begin{array}{l}\text { 2. Topik pembelajaran matematika hari } \\
\text { ini tidak penting untuk dipelajari (-). }\end{array}$ & 0,00 & 0,00 & 25,71 & 74,29 \\
\hline & $\begin{array}{l}\text { 3. Saya banyak berpikir pada } \\
\text { pembelajaran matematika hari ini }(+)\end{array}$ & 17,14 & 65,72 & 17,14 & 0,00 \\
\hline \multirow[t]{3}{*}{ Motivasi } & $\begin{array}{l}\text { 4. Saya berusaha sebaik mungkin untuk } \\
\text { mempelajari topik pembelajaran } \\
\text { matematika hari ini }(+) \text {. }\end{array}$ & 40,00 & 57,14 & 2,86 & 0,00 \\
\hline & $\begin{array}{l}\text { 5. Melalui aktivitas ini, saya percaya } \\
\text { bahwa saya mampu meningkatkan } \\
\text { kemampuan saya dalam penyelesaian } \\
\text { masalah matematika }(+) \text {. }\end{array}$ & 20,00 & 54,29 & 25,71 & 0,00 \\
\hline & $\begin{array}{l}\text { 6. Aktivitas ini membuat saya semakin } \\
\text { tidak termotivasi untuk belajar } \\
\text { matematika (-). }\end{array}$ & 0,00 & 0,00 & 31,43 & 68,57 \\
\hline \multirow[t]{2}{*}{$\begin{array}{l}\text { Strategi } \\
\text { mendalam }\end{array}$} & $\begin{array}{l}\text { 7. Saya berusaha mengkaitkan topik } \\
\text { pembelajaran hari ini dengan } \\
\text { permasalahan-permasalahan IPA }(+) \text {. }\end{array}$ & 40,00 & 60,00 & 0,00 & 0,00 \\
\hline & $\begin{array}{l}\text { 8. Di waktu senggang, saya tidak akan } \\
\text { mempelajari kembali topik yang telah } \\
\text { didiskusikan hari ini (-). }\end{array}$ & 0,00 & 8,57 & 68,57 & 22,86 \\
\hline
\end{tabular}

Berdasarkan tabel 2 diperoleh informasi bahwa pada indikator regulasi diri, mayoritas mahasiswa berusaha menghubungkan topik pembelajaran dengan konsep yang telah dipelajari sebelumnya. Masalah yang disajikan dapat dengan menerapkan konsep-konsep eksponen dan logaritma, sehingga mahasiswa harus mengingat kembali konsep tersebut. Mahasiswa juga menyadari bahwa topik eksponen dan logaritma penting untuk dipelajari. Hal ini didukung dengan respons positif bahwa mereka berusaha sebaik mungkin untuk mempelajari topik tersebut. Namun 
demikian, masih ada $25,71 \%$ mahasiswa yang merasa belum berusaha sebaik mungkin untuk mempelajari topik yang diajarkan. Sebagian besar mahasiswa percaya bahwa aktivitas gallery walk mampu meningkatkan kemampuan mereka dalam penyelesaian masalah matematika. Aktivitas ini juga diyakini mahasiswa dapat meningkatkan motivasi belajarnya. Pada indikator strategi mendalam, mayoritas mahasiswa mengaitkan konsep eksponen dan logaritma dengan permasalahan IPA. Konsep eksponen dan logaritma dapat digunakan untuk memecahkan masalah biologi tentang pembelahan bakteri, masalah fisika tentang intensitas bunyi dan peluruhan radiokatif, serta masalah kimia tentang penentuan $\mathrm{pH}$ suatu zat. Pada waktu senggang sebagian besar mahasiswa menyatakan akan mempelajari kembali topik yang sudah dibahas dan hanya 8,57\% mahasiswa menyatakan kurang setuju untuk mempelajari topik tersebut di waktu senggang mereka. Berdasarkan hasil tersebut dapat dinyatakan bahwa keterlibatan kognitif mahasiswa pada pembelajaran matematika dengan strategi gallery walk tergolong baik.

Keterlibatan kognitif adalah proses pembelajaran aktif. Menurut Fredricks, Blumenfeld, dan Paris (2004) keterlibatan kognitif diwujudkan dengan keterlibatan peserta didik dalam proses pembelajaran untuk memahami ide-ide kompleks dan menguasai keterampilan yang sulit melalui regulasi diri, metakognisi, dan strategi yang mendalam. Bowen (2005) menyatakan bahwa dimensi keterlibatan ini adalah bentuk keterlibatan yang paling mendasar yang berhubungan dengan apa yang peserta didik pikirkan dan akan dilakukan dalam pembelajaran. Menurut perspektif psikologi, Newmann, Wehlage, dan Lamborn mendefinisikan keterlibatan kognitif sebagai investasi psikologis dan upaya siswa yang diarahkan pada pembelajaran, pemahaman, atau penguasaan pengetahuan keterampilan (Kahu, 2013).

Persentase keterlibatan mahasiswa secara afektif dalam pembelajaran matematika dengan strategi gallery walk disajikan dalam tabel 3 berikut ini.

Tabel 3. Persentase keterlibatan afektif dalam pembelajaran matematika dengan strategi gallery walk

\begin{tabular}{|c|c|c|c|c|c|}
\hline \multirow[t]{2}{*}{ Indikator } & \multirow{2}{*}{ Item pernyataan } & \multicolumn{4}{|c|}{ Banyaknya responden $(\%)$} \\
\hline & & $\begin{array}{c}4 \\
(\mathrm{SS}) \\
\end{array}$ & $\begin{array}{c}3 \\
(\mathrm{~S}) \\
\end{array}$ & $\begin{array}{c}2 \\
(\mathrm{KS}) \\
\end{array}$ & $\begin{array}{c}1 \\
(\mathrm{TS})\end{array}$ \\
\hline \multirow[t]{4}{*}{ Ketertarikan } & $\begin{array}{l}\text { 1. Saya senang belajar matematika } \\
\text { dalam kelompok kecil }(+) \text {. }\end{array}$ & 74,29 & 25,71 & 0,00 & 0,00 \\
\hline & 2. Pembelajaran hari ini membosankan (-). & 0,00 & 0,00 & 14,29 & 85,71 \\
\hline & $\begin{array}{l}\text { 3. Saya tertarik menyelesaikan masalah } \\
\text { matematika yang disajikan }(+)\end{array}$ & 42,86 & 48,57 & 8,57 & 0,00 \\
\hline & $\begin{array}{l}\text { 4. Belajar matematika dengan strategi } \\
\text { gallery walk menyenangkan }(+) \text {. }\end{array}$ & 77,14 & 22,86 & 0,00 & 0,00 \\
\hline \multirow{3}{*}{$\begin{array}{l}\text { Orientasi } \\
\text { terhadap } \\
\text { prestasi }\end{array}$} & $\begin{array}{l}\text { 5. Saya senang dapat menyelesaikan } \\
\text { masalah yang disajikan }(+) \text {. }\end{array}$ & 85,71 & 14,29 & 0,00 & 0,00 \\
\hline & $\begin{array}{l}\text { 6. Saya puas mendapatkan nilai yang } \\
\text { baik setelah berusaha dengan } \\
\text { sungguh-sungguh }(+) \text {. }\end{array}$ & 85,71 & 14,29 & 0,00 & 0,00 \\
\hline & $\begin{array}{l}\text { 7. Usaha untuk menyelesaikan masalah } \\
\text { eksponen dan logaritma tidak } \\
\text { bermanfaat bagi saya (-). }\end{array}$ & 0,00 & 0,00 & 37,14 & 62,86 \\
\hline Orientasi & 9. Saya lebih paham masalah eksponen & 68,57 & 17,14 & 14,29 & 0,00 \\
\hline
\end{tabular}




\begin{tabular}{|c|c|c|c|c|c|}
\hline \multirow{4}{*}{$\begin{array}{l}\text { terhadap } \\
\text { teman } \\
\text { sejawat }\end{array}$} & \multicolumn{5}{|l|}{$\begin{array}{l}\text { dan logaritma ketika belajar dengan } \\
\text { teman }(+) \text {. }\end{array}$} \\
\hline & $\begin{array}{l}\text { 10.Diskusi kelompok mematikan } \\
\text { kreativitas (-). }\end{array}$ & 0,00 & 5,71 & 74,29 & 20,00 \\
\hline & $\begin{array}{l}\text { 11. Saya merasa lebih dekat dengan teman } \\
\text { sekelompok }(+) \text {. }\end{array}$ & 71,43 & 28,57 & 0,00 & 0,00 \\
\hline & $\begin{array}{l}\text { 12. Saya berkomunikasi dengan baik } \\
\text { antar teman sekelompok maupun } \\
\text { kelompok lain }(+) \text {. }\end{array}$ & 91,43 & 8,57 & 0,00 & 0,00 \\
\hline
\end{tabular}

Keterangan: SS: Sangat setuju; S: Setuju; KS: Kurang setuju; TS: Tidak Setuju

Berdasarkan tabel 3 diperoleh informasi bahwa keterlibatan afektif mahasiswa pada indikator ketertarikan menunjukkan respons yang positif. Penerapan strategi gallery walk menyenangkan dan tidak membosankan bagi mahasiswa. Sebagian besar mahasiswa menyatakan senang belajar dalam kelompok kecil dan tertarik untuk menyelesaikan masalah yang disajikan. Ketika masalah yang disajikan berhasil diselesaikan, sebagian besar mahasiswa menyatakan senang dan puas dengan usahanya. Hal ini menunjukkan bahwa orientasi mahasiswa terhadap prestasi tergolong cukup baik. Menurut Redmond, dkk (2018) keterlibatan afektif yang positif akan ditampilkan oleh seseorang yang menghargai pembelajaran, menghargai proses memperoleh pengetahuan dan keterampilan, dan menghargai kesuksesan. Hal serupa juga ditunjukkan pada indikator orientasi terhadap teman sejawat. Mahasiswa merasa lebih dekat dengan teman dan mampu berkomunikasi dengan baik dengan sesama kelompok maupun antar kelompok. Diskusi kelompok untuk menyelesaikan masalah eksponen dan logaritma memacu kreativitas dan membuat mahasiswa memahami konsep matematika dengan lebih baik. Dengan demikian dapat disimpulkan bahwa keterlibatan mahasiswa secara afektif pada pembelajaran matematika dengan strategi gallery walk tergolong baik.

Dimensi keterlibatan afektif adalah kekuatan dari pendekatan psikologis karena terdapat intensitas emosional yang melekat pada pengalaman belajar yang sering diabaikan (Askham, 2008). Keterlibatan afektif diwujudkan dengan emosi langsung, misalnya ketertarikan dan kenyamanan peserta didik dalam menyelesaikan tugas (Furlong, dkk, 2003). Keterlibatan ini berhubungan langsung dengan emosi dan perasaan. Sinatra, Heddy, dan Lombardi (2015) dalam penelitiannya menjelaskan bahwa baik emosi negatif maupun positif keduanya dapat memfasilitasi seseorang untuk memfokuskan perhatian dan mendorong partisipasi dalam pembelajaran.

Menurut Kong, Wong, dan Lam (2003) keterlibatan perilaku peserta didik terkait erat dengan keterlibatan kognitif dan afektif mereka. Secara umum keterlibatan perilaku mahasiswa dalam pembelajaran matematika dengan strategi gallery walk tergolong baik. Hasil observasi menunjukkan bahwa banyaknya mahasiswa yang aktif bertanya yaitu $34,29 \%$ dan terdapat mahasiswa yang tidak pernah bertanya dengan persentase sebesar 14,29\%. Beberapa mahasiswa tidak pernah bertanya karena mereka telah memahami konsep dan mampu menyelesaikan masalah, sehingga mereka lebih banyak menjelaskan kepada teman lain yang membutuhkan bantuan. Semua mahasiswa terlihat aktif berdiskusi dengan frekuensi yang berbedabeda. Sebanyak $65,71 \%$ mahasiswa sering terlibat aktif dalam diskusi. Indikator ini sering tampak ketika mahasiswa mencoba menyelesaikan masalah eksponen dan logaritma dalam kelompok kecil. Strategi gallery walk menuntut semua mahasiswa memahami hasil diskusinya. Selanjutnya, setiap mahasiswa menjelaskan hasil 
diskusi pada kelompok yang lain. Hasil observasi pada indikator "frekuensi menjelaskan pada teman" menunjukkan bahwa semua mahasiswa aktif menjelaskan dengan frekuensi sering sebesar $65,71 \%$ dan frekuensi kadang-kadang sebesar $34,29 \%$. Adapun data hasil observasi disajikan pada gambar 1 berikut ini.

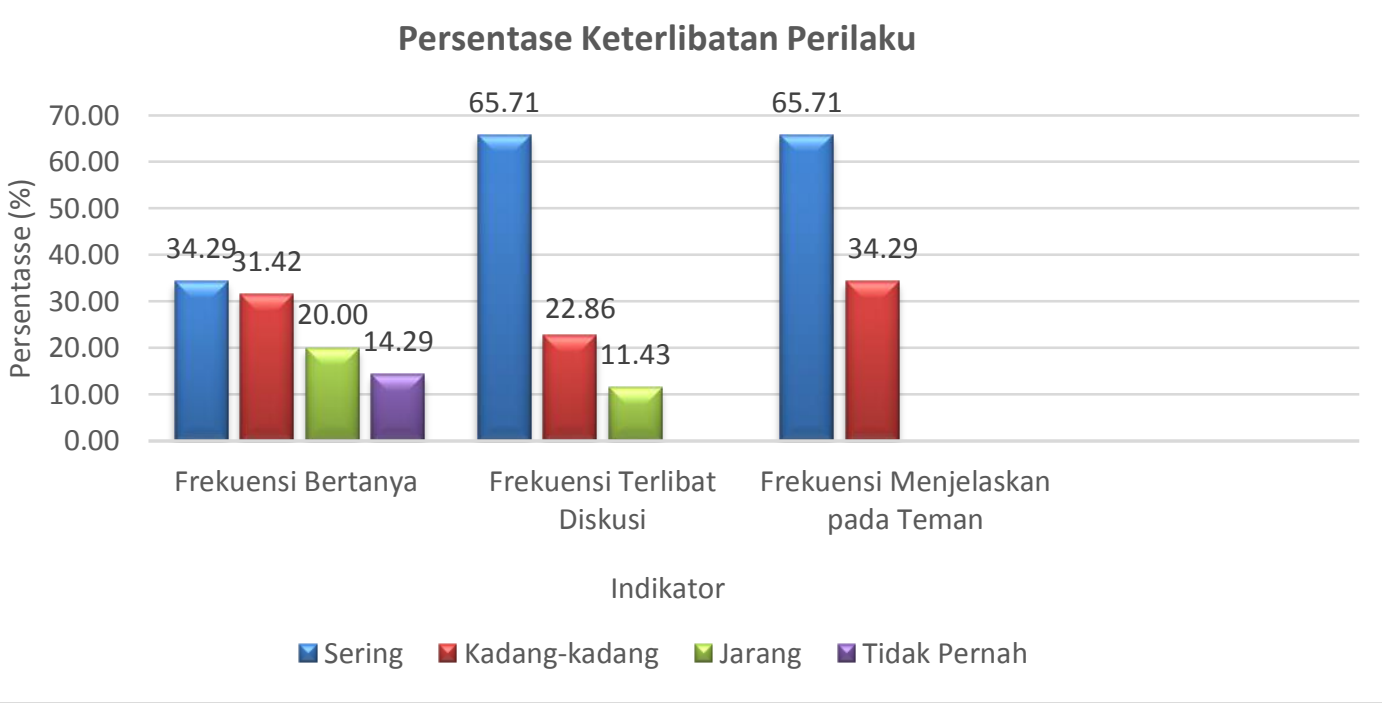

Gambar 1. Persentase keterlibatan perilaku dalam pembelajaran matematika dengan strategi gallery walk

Seseorang yang memilki keterlibatan perilaku yang baik memiliki ciri-ciri bersikap positif dalam pembelajaran, berpartisipasi aktif, terlibat dalam penyelesaian tugas, berusaha dengan gigih, dan mampu mengatur diri sendiri dengan baik (Young, 2010). Mereka tahu dengan pasti kapan mencari bantuan dan kapan membantu teman lain yang membutuhkan. Keterlibatan ini mencakup beberapa keterampilan seperti komunikasi lisan dan tulisan, perencanaan, manajemen waktu, dan penetapan tujuan (Pittaway and Moss, 2014).

Jika dilihat dari pandangan matematika, keterlibatan muncul ketika mahasiswa menikmati pembelajaran matematika, mahasiswa menghargai proses belajar matematika dan melihat relevansi matematika dengan ilmu-ilmu lainnya, mahasiswa melihat hubungan antara konsep-konsep matematika yang mereka pelajari dengan masalah-masalah yang mereka temui dalam kehidupan sehari-hari (Attard, 2012). Untuk itu diperlukan desain pembelajaran dengan strategi yang menyenangkan, konten yang mengaitkan konsep dengan masalah-masalah di bidang lain dan berhubungan dengan kehidupan sehari-hari. Dalam pembelajaran matematika di perguruan tinggi, pertimbangan pertama desain pembelajaran adalah untuk membuat siswa belajar dengan mudah karena topik pembelajaran matematika di perguruan tinggi relatif lebih sulit. Strategi gallery walk sesuai dengan tujuan tersebut. Menurut Bowman (2005) strategi gallery walk menghubungkan peserta didik dengan teman sejawatnya dan topik yang diajarkan dalam bebagai cara yang menarik dan interaktif. Hal ini sejalan dengan pendapat Tan dan Alcantara (2017) bahwa dalam pembelajaran dengan strategi gallery walk, mahasiswa dihadapkan pada situasi kelas yang santai dan secara psikologis dapat mengurangi stres. Strategi ini memungkinkan mahasiswa secara aktif terlibat saat diskusi kelompok maupun saat berkeliling untuk melihat dan memahami hasil diskusi kelompok lain. Strategi ini juga sesuai untuk mahasiswa dengan gaya belajar kinestetik karena terdapat aktivitas 
ekshibisi/pameran yang membutuhkan keterlibatan secara fisik (Dinata and Anggraini, 2017).

\section{SIMPULAN DAN SARAN}

Strategi gallery walk dapat diterapkan pada pembelajaran matematika di perguruan tinggi karena dapat mengoptimalkan keterlibatan mahasiswa dalam pembelajaran. Dalam pembelajaran matematika untuk calon guru IPA, penerapan strategi ini perlu dilengkapi dengan aktivitas problem solving yang berkaitan dengan masalah-masalah IPA. Berdasarkan hasil penelitian yang telah dilakukan, dapat disimpulkan bahwa keterlibatan kognitif mahasiswa yang meliputi regulasi diri, motivasi, dan strategi mendalam tergolong baik. Keterlibatan afektif yang mengukur ketertarikan akan pembelajaran, orientasi terhadap prestasi dan teman sejawat juga tergolong baik. Pada keterlibatan perilaku dengan indikator frekuensi bertanya, terlibat diskusi, dan menjelaskan pada teman sejawat menunjukkan hasil yang baik pula.

Penelitian ini menggunakan teknik angket dan observasi dalam pengumpulan data. Penelitian ke depan yang berfokus pada keterlibatan mahasiswa dapat dilengkapi dengan teknik wawancara agar diperoleh informasi lebih mendalam tentang alasan keterlibatan mahasiswa baik afektif, kognitif, maupun perilaku. Optimalisasi keterlibatan mahasiswa dalam pembelajaran matematika juga dapat dikembangkan melalui strategi-strategi pembelajaran yang lain.

\section{DAFTAR PUSTAKA}

Allen, C., and Larmer, J. 2013. Using Gallery Walks for Revision and Reflection. Buck Institute for Education (BIE). [online]. Tersedia: http://www.bie.org. [10 Oktober 2019].

Askham, P. 2008. Context and identity: Exploring adult learners' experiences of higher education. Journal of Further and Higher Education, Vol. 32 : 85-97.

Attard, C. 2012. Engagement with mathematics: What does it mean and what does it look like?. Australian Primary Mathematics Classroom, Vol. 17(1) : 913.

Beckers, R., van der Voordt, T., and Dewulf, G. 2015. A conceptual framework to identify spatial implications of new ways of learning in higher education. Facilities, Vol. 33(1/2) : 2-19.

Bowen, S. 2005. Engaged learning: Are we all on the same page? Peer Review, 4-7.

Bowman, S. L. 2005. The Gallery Walk: An Opening, Closing, Review Activity. Glenbrook: Bowperson Publishing and Training, Inc.

Chapman, E. 2003. Alternative approaches to assessing student engagement rates. Practical Assessment, Research \& Evaluation, Vol. 8(13) : 1-7.

Chen, P., Lambert, A., and Guidry, K. 2010. Engaging online learners: The impact of web-based learning technology on college student engagement. Computers \& Education, Vol. 54 : 1222-1232. doi: 10.1016/j.compedu.2009.11.008.

Dinata, H. and Anggraini, R.W. 2017. The Use of Gallery Walk Too Enhance The Speaking Achievement of The Ninth Grade Students of SMP PGRI 1 Palembang. Jurnal Bahasa \& Sastra, Vol. 6(1) : 50-56.

Fredricks, J., Blumenfeld, P., and Paris, A. 2004. School Engagement: Potential of the concept, and state of the evidence. Review of Educational Research, Vol. 74 : 59-109. 
Furlong, M. A., et al. 2003. Multiple Contexts of School Engagement: Moving Toward a Unifying Framework for Educational Research and Practice. The California School Psychologist, Vol. 8 : 99-113.

Kahu, E. R. 2013. Framing Student Engagement in Higher Education. Studies in Higher Education, Vol. 38(5) : 758-773, DOI: 10.1080/03075079.2011.598505.

Kong, Q.P., Wong, N.Y., and Lam, C.C. 2003. Student Engagement in Mathematics: Development of Instrument and Validation of Construct. Mathematics Education Research Journal, Vol. 15(1) : 4-21.

Kuh, G. D. 2003. What We're Learning About Student Engagement From NSSE: Benchmarks for Effective Educational Practices. Change, Vol. 35(2) : 24-32.

Liu, X. 2012. On the Student-centered Idea. Journal of Higher Education, Vol. 33 : 1-6.

Mandernach, B.J. 2015. Assessment of Student Engagement in Higher Education: A Synthesis of Literature and Assessment Tools. International Journal of Learning, Teaching and Educational Research, Vol. 12(2) : 1-14.

Pagán, J. E. 2018. Behavioral, Affective, and Cognitive Engagement of High School Music Students: Relation to Academic Achievement and Ensemble Performance Ratings. Graduate Theses and Dissertations. [online]. Tersedia: https://scholarcommons.usf.edu/etd/7347. [10 Oktober 2019].

Pittaway, S., and Moss, T. 2014. Initially, We Were Just Names on a Computer Screen: Designing Engagement in Online Teacher Education. Australian Journal of Teacher Education, Vol. 39(7) : 37-45, doi:10.14221/ajte.2014v39n7.10.

Qomaria, N. 2017. Using Formulator Tarsia to Create Collaborative Activities in Mathematics Classroom. Proceeding International Conference on Islamic Education (ICIED) UIN Maulana Malik Ibrahim Malang, 23-24 November 2019. Vol. 2, 361-366. e-ISSN: 2613-9804.

Redmond, P., Heffernan, A., Abawi, L., Brown, A., and Henderson, R. 2018. An Online Engagement Framework for Higher Education. Online Learning, Vol. 22(1) : 183-204. doi:10.24059/olj.v22i1.1175.

Septiana, D. A. and Sunarti, T. 2019. The Implementation of Problem Based Learning with Gallery Walk Strategy on Global Warming. IPF: Inovasi Pembelajaran Fisika, Vol. 8(2) : 692-695.

Sinatra, G., Heddy, B., and Lombardi, D. 2015. The Challenges of Defining and Measuring Student Engagement in Science. Educational Psychologist, Vol. 50(1) : 1-13. doi:10.1080/00461520.2014.1002924.

Tan, C. and Alcantara., M. C. 2017. Gallery Walk Technique in Teaching Selected Topics in English and Learners' Performance. International Journal of Advanced Research, Vol. 5(3) : 1000-1002. doi: 10.21474/IJAR01/3598.

Wilson, M. E. 2004. Teaching, Learning, and Millennial Students. New Directions for Student Services, Vol. 106 : 59-71.

Young, M. R. 2010. The Art and Science of Fostering Engaged Learning. Academy of Educational Leadership Journal, Vol. 14(Special Issue) : 1-18.

Zhu, K. 2018. Discussion on The Student-Centered Teaching of College Mathematics. American Journal of Educational Science, Vol. 4(4) : 144-148. 